\title{
Intradermal influenza vaccination in complete remission cancer patients: molecular insights
}

\author{
Davide Bedognetti ${ }^{*}$, Maria Libera Ascierto ${ }^{1}$, Marimo Sato-Matsushita', Elena Gugiatti ${ }^{2}$, Carlotta Massucco ${ }^{2}$, \\ Simonetta Zupo ${ }^{2}$, Antonio Di Meglio², Chiara Dellepiane ${ }^{2}$, Mario Roberto Sertoli ${ }^{2}$, Omar Racchi ${ }^{2}$, Enrico Balleari ${ }^{2}$, \\ Valeria De Giorgi ${ }^{1}$, Michele Sommariva ${ }^{1}$, Paolo Durando ${ }^{2}$, Manlio Ferrarini ${ }^{2}$, Roberto Cacciani ${ }^{2}$, Nicoletta Provinciali ${ }^{2}$ \\ , Rocco ludici ${ }^{2}$, Cristiano Alicino ${ }^{2}$, Ena Wang ${ }^{1}$, Filippo Ansaldi ${ }^{2}$, Francesco M Marincola ${ }^{3,1}$, Andrea De Maria ${ }^{2}$
}

From Society for Immunotherapy of Cancer 28th Annual Meeting

National Harbor, MD, USA. 8-10 November 2013

We previously showed that long-lasting complete remission (CR) non-Hodgkin lymphoma (NHL) patients treated with rituximab-containing chemotherapy have an attenuated antibody response to virosomal (Bedognetti et al, J. Immunology, 2011) or MF-59 adjuvanted (Bedognetti et al, Blood, 2012) seasonal (or pandemic) influenza vaccine (as compared with healthy controls), associated with persistent CD27+ Memory B cell depletion and hypogammaglobulinemia. Here, we evaluated humoral and innate response to trivalent intradermal vaccination in NHL in CR previously treated with rituximab-containing chemotherapy (at least one year before vaccine administration), RIT group, and in CR cancer patients treated with chemotherapy without rituximab (at least one year before vaccine administration), Non-RIT group. Intradermal administration was chosen considering its promising data, compared to conventional intramuscular route, in terms of immunogenicity and safety. Humoral response was assessed by hemagglutinin inhibition assay on sera collected at time 0 (just before vaccination) and at time 28 (four weeks after vaccination). Innate response was assessed by whole-genome gene expression analysis (Affymetrix Humane Gene ST 1.0) on PBMC collected at time 0 and at time 1 (24 hours after vaccine administration). Patients treated with rituximab-containing chemotherapy had, overall, a lower antibody response, compared to patients treated with chemotherapy alone. Overall, intradermal vaccination induced dramatic changes in gene-expression profile already one day after vaccination. These changes underline the activation of IFN stimulated genes (eg, STAT1, STAT2, CXCL10, IDO1, GBP1)

\footnotetext{
${ }^{1}$ DTM, NIH, Bethesda, MD, USA
}

Full list of author information is available at the end of the article and modulation of NK-associated transcripts. In addition, pathway and gene-enrichment analysis show that RIT and non-RIT groups have different quantitative and qualitative transcriptomic changes 24 hours after vaccination administration. Concordantly with antibody-titer, the innate response was more intense in Non-RIT group compared with RIT group.

\section{Authors' details}

${ }^{1}$ DTM, NIH, Bethesda, MD, USA. ${ }^{2}$ IRCCS San Martino-Ist, Genova, Italy. ${ }^{3}$ Sidra Medical and Research Centre, Doha, Qatar.

Published: 7 November 2013

doi:10.1186/2051-1426-1-S1-P197

Cite this article as: Bedognetti et al:: Intradermal influenza vaccination in complete remission cancer patients: molecular insights. Journal for ImmunoTherapy of Cancer 2013 1(Suppl 1):P197.

Submit your next manuscript to BioMed Central and take full advantage of:

- Convenient online submission

- Thorough peer review

- No space constraints or color figure charges

- Immediate publication on acceptance

- Inclusion in PubMed, CAS, Scopus and Google Scholar

- Research which is freely available for redistribution

Submit your manuscript at www.biomedcentral.com/submit
Ciomed Central

(c) 2013 Bedognetti et al; licensee BioMed Central Ltd. This is an Open Access article distributed under the terms of the Creative Commons Attribution License (http://creativecommons.org/licenses/by/2.0), which permits unrestricted use, distribution, and reproduction in any medium, provided the original work is properly cited. 